JEL classification: G31, L24, E64

\title{
RETROSPECTIVE ANALYSIS OF REPRODUCTION PROCESSES OF FIXED CAPITAL OF RAILWAY TRANSPORT
}

\author{
CGulamov A., SPIN-code: 1299-2984, ORCID: 0000-0002-4702-7468, Ph.D., \\ Tashkent institute of railways engineers, Tashkent, Uzbekistan, abdulaziz.gulamov@gmail.com

\section{РЕТРОСПЕКТИВНЫЙ АНАЛИЗ ВОСПРОИЗВОДСТВЕННЫХ ПРОЦЕССОВ ОСНОВНОГО КАПИТАЛА ЖЕЛЕЗНОДОРОЖНОГО ТРАНСПОРТА}

CГУламов A. A., SPIN-код: 1299-2984, ORCID: 0000-0002-4702-7468, канд. экон. наук, Ташентский институт инженеров железнодорожного транспорта, г. Ташкент, Узбекистан, abdulaziz.gulamov@gmail.com

Abstract. Joint-stock company "Uzbek Railways" is the largest transport company in the country and in some segments of the transport market works in conditions of tough competition. With the development of market relations and economic growth, as well as competitive pressure from other participants in the transport market, reliable condition, efficient use and intensive reproduction of fixed assets are becoming increasingly important. In this regard, the research and development of effective methods of the reproductive process of the railway company. In this article, a retrospective analysis of the reproduction of the fixed capital of a railway company is carried out and suggestions are given for the intensification of this process.

Аннотащия. Акционерное общество «Узбекские железные дороги» является крупнейшей транспортной компанией страны и в отдельных сегментах транспортного рынка работает в условиях жесткой конкуренции. В условиях развития рыночных отношений и экономического роста, а также конкурентного давления со стороны других участников транспортного рынка все большее значение приобретает надежное состояние, эффективное использование и интенсивное воспроизводство основных фондов. В связи с этим исследование и разработка эффетивных методов воспроизводственного процесса железнодорожной компании. В данной статье проводится ретроспективный анализ воспрозводства основного капитала железнодорожной компании и даются предложения по интенсификации данного процесса.

Keywords: depreciation, fixed assets, intensification, railway transport.

Ключевые слова: амортизация, основные фонды, интенсификация, железнодорожный транспорт.

\section{Introduction}

Modern concepts of reproduction and use of fixed assets are based on the theory of the functioning of capital as a production factor.

Capital theory is traditionally characterized by specialists as one of the most complex. It has a deep genesis, and these problems have aroused the interest of researchers since the inception of economics. 
The specificity of the evolution of the concepts of capital is their close connection with the dominant paradigm of the analysis of the development of society. Thus, at the early stage of the formation of science, theoretical trends in economics were considered in the applied aspect of studying artisan and commercial activities.

In accordance with the worldview of mercantilists, foreign trade was considered to be a priority area for the efficient circulation of capital. The essence of wealth and prosperity in this early course of economic thought is seen as the accumulation of money. As M. Blaug describes, quoting Charles Wilson, Britain of the XVII-XVIII centuries. in foreign trade with the Baltic and colonial countries simply did not possess anything that would be an attractive commodity for exchange.

The School of Economics of Physiocrats focused on the forms and mechanisms of capital utilization in agriculture. In this case, land and funds invested in it were considered as the basis of capital. F. Quesnay - the great French economist of the XVIII century. and his supporters believed that the source of wealth is the labor of agricultural workers, creating a surplus in excess of the product that is necessary for their existence. These political and economic theories rejected mercantilism for the unproductiveness of money capital and the reassessment of the role of trade. They sought for the external manifestations of wealth (primarily in trade and money circulation) to reveal its true nature. From the physiocratic concept, the primary concept of net income as a gift of nature, rent, a single tax, as well as the law of the BBB markets came to the scientific economy. Seya, who revealed the connectedness of supply and demand, and became, in essence, a continuation of this approach [1].

A brief description of the investigation of the issue and justification of the novelty of the questions that the authors consider in the article are given.

\section{Material and research methods}

This paper is describing research material and methodology of depretiation of fixed assets of the railway transport. The fundamental basis for the knowledge of capital as a category that has a complex economic, philosophical and legal nature, in classical political economy was laid by the English economist William Petty in the second half of the 17th century. A characteristic feature of his research was that they first began to study property relations in an internal relationship with the production relations of people. It is on the basis of these prerequisites that a classical approach was subsequently formed in economic theory, based on the concept of capital circulation and the creation of a surplus.

\section{Results and discussion}

The sphere of industrial production was introduced into the economic theory by A. Smith and D. Ricardo. L. Smith long before D. Ricardo and K. Marx substantiated the basic principles of the origin, formation and functioning of capital. In the works of A. Smith for the first time appears the division of productive capital into fixed and circulating. The division of capital used in the production process into main and negotiable is determined not only by the characteristics of the turnover of each of its constituent parts, but also by the method of transferring their value to the product (goods, services) produced in the process of transformation from the productive form to the commodity form.

The cycle diagram of the cycle of production capital used in modern management concepts was formed much later, but nevertheless, in A. Smith's works all the basic prerequisites for its creation were laid. 
In the works of D. Ricardo considerable attention is paid to the study of the means of production. The appeal of modern economists to the works of Ricardo occurs whenever the paradigm of the economy and its apparatus changes.

Studies on the use of capital occupy a central place in Marx's teaching. In the Marxist concept, capital appears in concrete forms - in the means of production (constant capital), money (money capital), people (variable capital), goods (commodity capital). According to the listed material carriers, they are capital not by themselves, but represent a special production relationship in direct connection with depreciation and reproduction of fixed assets.

In classical economic theory, questions of the methodology for using depreciation deductions were practically not raised due to the fact that business practice did not require the economic theory to solve this issue. Nevertheless, K. Marx discussed the problem of compensation for the fixed capital in the course of his correspondence with F. Engels. In a letter to Engels dated August 24, 1867, Marx asked for an answer to the question: "You, as a manufacturer, should know what you are doing with the money coming in to repay the fixed capital before the time when it must be replaced in natura. And you must answer me this question (without theory, purely practical). " Answering the question, F. Engels described in detail the practice of using the amounts of the "renewal fund." This practice still occurs today when making decisions on the use of depreciation funds.

The neoclassical economic theories of using capital significantly deepened some of the essential characteristics of this process and proceeded to solve the problems of quantitative measurement of the parameters of its flow. At this stage of development of economic thought, concepts of normative greatness began to appear as points of reference, which marked the beginning of the formation of a normative approach.

At the end of the 20th century, such scholars as V. Zombart, E. Bem-Bawerk, P. Sraffa, X. Kurtz, as well as neo-Ricardian economists J. Steedman and L. Mainvoring made a significant contribution to the study and development of capital capital issues. B. Sheffold. Relying on the classical economic theory of A. Smith, D. Ricardo and K. Marx, they developed it by examining the questions of the formation of the value of capital. A Japanese economist Sh. Hoshimura based on the theory of capital K. Marx built mathematical models of reproduction and capital accumulation.

Despite the idealization of modern Western economic science in Russia, it should be noted that in the west the theory of Karl Marx's capital is far from being forgotten by everyone. As P. Samuelson said, "Marxism is too valuable to leave it alone to Marxists" [3].

Along with the concept of "fixed capital", the concepts of "fixed assets" and "fixed assets" are used in theory and practice. The concept of "fixed assets" is interpreted as "a set of tangible assets operating for a long time: buildings, structures, machinery, equipment, vehicles, etc.", and "fixed assets" — as "basic funds in monetary terms "'". However, in the practice of economic work of business entities and even in official legal documents there is no clear distinction between these concepts. Fixed assets and fixed assets are often used as synonyms. The fixed capital is a part of production capital (the cost of machinery, equipment, buildings, structures), which transfers its value, the newly created product in parts and returns to the capitalist in monetary form gradually, but the degree of wear and tear during a series of capital cycles. In the modern economic sphere, the acquisition of fixed capital is identified with fixed assets. So, in the Big Economic Dictionary will be given the following definition: "The main capital, fixed assets are the fixed assets necessary for the company to carry out its production activities, the depreciation period of which exceeds one year.

Economic theory analyzes the nature of capital associated with the time factor. Time is treated as an independent factor, creating income. 
The time factor has been studied in detail in the theory of evaluating the effectiveness of investment projects. It is studied in three dimensions: dynamism; se-zoning; physical deterioration of fixed assets (deterioration).

Depreciation of fixed assets causes general tendencies to decrease in their productivity and increase in costs for their maintenance, operation and repair during the billing period.

The modern approach to the theory of capital, significantly different from the traditions of past years, at the same time continues to use and develop approaches of classical political economy, guided by the fundamental principle, the essence of which is that in any formation social production is based on the use of fixed assets full circuit.

The main production capital in the process of the full cycle of the cycle goes through three stages:

$$
\text { (stage } 1) \mathrm{OK}_{\mathrm{d}} \rightarrow \mathrm{OK}_{\mathrm{pr}} \rightarrow(\text { stage } 2) \ldots \text { i. o.c. } \ldots \rightarrow \mathrm{O}(\text { stage } 3) \mathrm{K}_{\mathrm{t}} \rightarrow \mathrm{OK}_{\mathrm{d}}(\mathrm{AF})
$$

At stage 1, the main production capital in cash $\left(\mathrm{OK}_{d}\right)$ is advanced into the means of labor, taking respectively the form of productive fixed capital $\left(\mathrm{OK}_{p r}\right)$.

At stage II, fixed assets in productive form $\left(\mathrm{OK}_{p r}\right)$ gradually transfer their value in parts as they wear out (i.o.c.) to their products (goods, services), transforming into a certain part of capital $\left(\mathrm{OK}_{t}\right)$. This process is carried out in the course of many production cycles and continues until the complete depreciation of certain types of means of labor, in which the fixed capital is advanced.

At stage III, in the process of selling products, its part of the cost of fixed capital in the commodity form $\left(\mathrm{OK}_{t}\right)$ is converted into fixed capital in cash $\left(\mathrm{OK}{ }_{d}\right)$ which is called the "amortization fund" (AF). As it accumulates funds of a depreciation fund, fixed capital in cash is again ready for advances to the means of labor, carried out through their repair or the acquisition of new analogues.

Expanding the scheme of circulation, the researchers clarify the nature of wear and mechanisms of capital reproduction.

Thus, capital, taking various forms, is a necessary resource for carrying out the economic activity of any organization. The main phase of capital turnover in railway transport is the productive captain, and first of all, as indicated below, and the form of the means of labor.

In economics, the following concepts are used that characterize productive capital in the form of means of labor: fixed capital, fixed assets, and fixed assets. The use of these concepts in the modern economic science introduces certain difficulties in understanding the economic relations that arise during the transition from one phase of capital movement to another. A number of authors believe that the terms "fixed capital" and "Fixed assets" are identical [4]. Others use the term "fixed capital" to mean the set of fixed assets of an enterprise and investments in fixed assets [5].

Until now, economics has no uniform understanding of the essence of the concepts "fixed assets" and "fixed assets." Some economists believe that "fixed assets" is a term of economics, and "fixed assets" is a term used in accounting [6]. Others define the concept of "fixed assets" as the denotation for "fixed assets" [7,8]. Still others, on the contrary, define the concept of "fixed assets" as the monetary expression of "fixed assets" [9, 10]. The fourth identify these concepts [11, 12]. There is no uniformity in economic dictionaries [13]. An analysis of normative legal acts [14] showed that the concepts of "fixed assets" and "fixed assets" are identical from these positions.

Fixed assets - is part of the means of labor, participating entirely in the production or management process, acting in an unchanged natural form for a long period and reimbursing their value as they wear out in the form of depreciation deductions included $\mathrm{n}$ cost of products or services that contribute to economic benefits (income). 


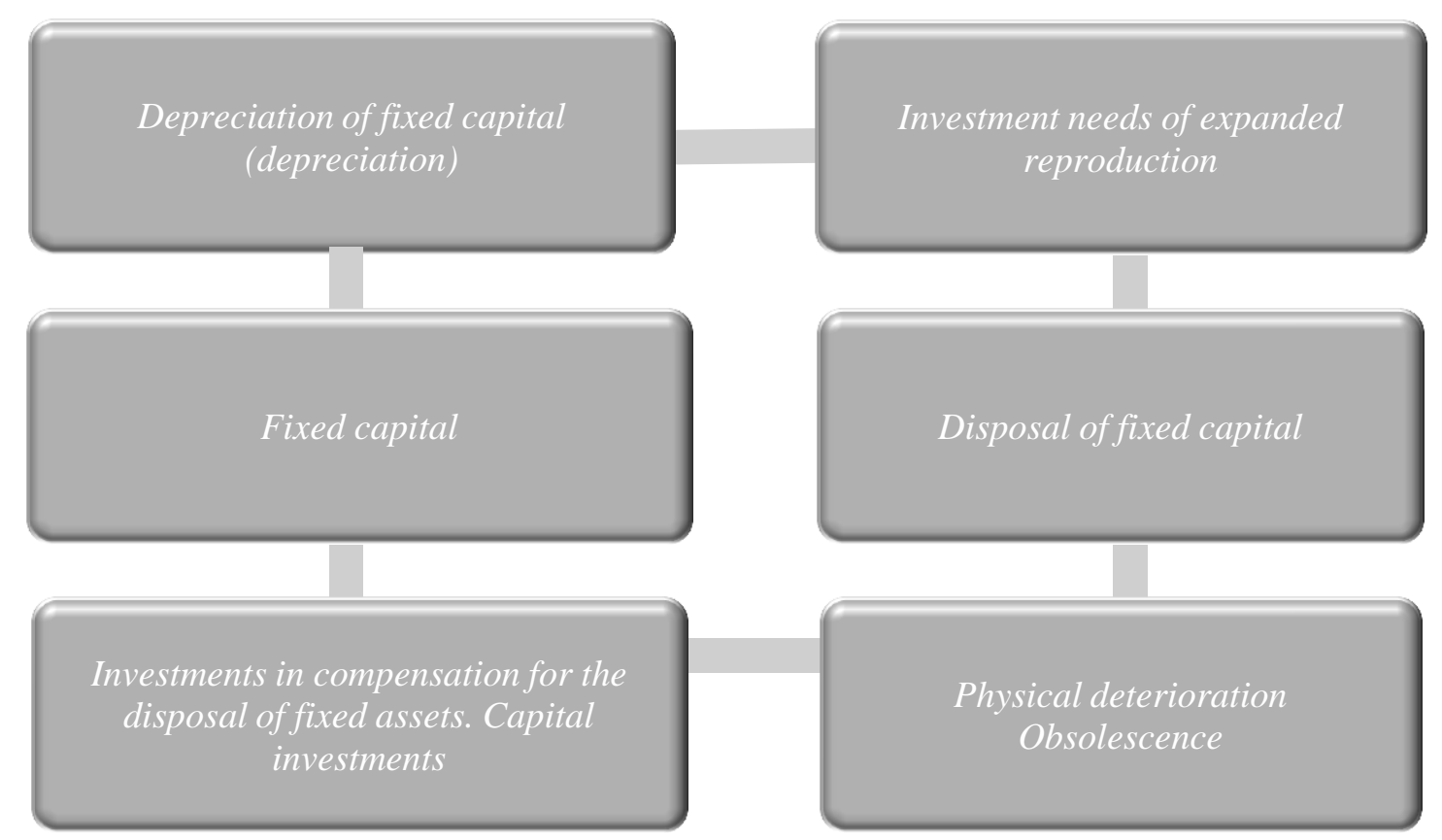

Figure 1. Capital reproduction scheme

The means of labor include tools of labor, t.s. What is the process of production, as well as buildings, structures, devices, i.e. what provides the production process. K. Marx noted that economic epochs differ not by what is produced, but by how it is produced by what means, therefore it is necessary to study the patterns of development of the means of labor and use the knowledge gained in practice and the goals of increasing production efficiency as a whole. The means of labor are a real-material category, and economics as science operates with economic categories. Therefore, for their characteristics they use, as a rule, the economic category - fixed assets.

To assign the object under study to this category, the following features are highlighted. Firstly, participation in the production process is a goal. Secondly, the action and unchanged natural form and for a long period. Third, the reimbursement of its value as it depreciates in the form of depreciation deductions included in the cost of products or services. Fourthly, the excess of its value of the established limit for assignment to objects and circulation [15]. For the purposes of this study, fixed capital should be understood as capital embodied or embodied in fixed assets. If embodied fixed capital characterizes the phase of its productive use, then capital embodied in fixed assets is characterized by the phase of its reinvestment.

Assessment of the effectiveness of the use of fixed assets, $p$, therefore, the capital embodied in them, and the effectiveness of investments in their reproduction, and, consequently, the capital embodied in them adequately to external conditions is impossible without a scientifically based classification of fixed assets and investments.

The classification of the studied objects means their distribution into specific groups according to certain characteristics in order to achieve the goal set by the researcher. Classification sign is a distinctive feature of a particular group, the main feature that distinguishes it from other groups.

Classification of fixed assets allows you to clearly define the place of each asset in the general system and its distinctive characteristics. This creates the possibility of effective use of methods and methods of management, evaluation of the effectiveness of use, determining the dynamics of change, assessment of capitalization, etc., corresponding only to this group of fixed assets. 


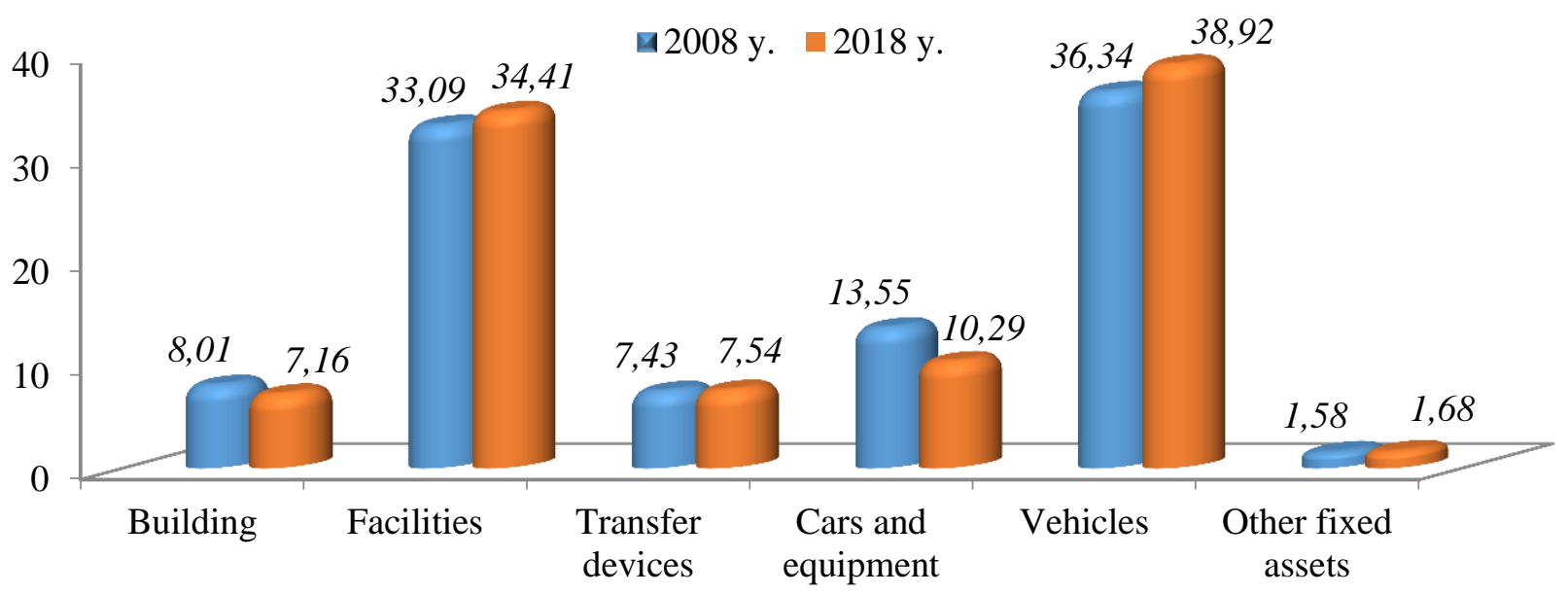

Figure 2. Species structure of the share capital of JSC "Uzbekistan Railways"

An analysis of the specific structure of the fixed capital of railway transport shows that the main share is occupied by buildings and vehicles (more than 70\%). The share of structures increased from $33.09 \%$ to $34.41 \%$, the share of vehicles also increased from $36.34 \%$ to $38.92 \%$. This is primarily due to the fact that over the past decades new lines have been actively introduced, such as Tashguzar-Baysun-Kumkurgan, Pap-Angren, and others. The active part of fixed capital, such as electric locomotives and rolling stock, is being updated.

In recent years, in general, the enterprises of society have seen a positive trend in the ratio between input rates and rates of disposal of fixed capital, which has led to a decrease in physical deterioration and moral depreciation of funds, as well as to an improvement in the age structure (Table 1).

Table 1

INDICATORS OF THE REPRODUCTION PROCESS OF THE SHARE CAPITAL OF THE JSC "UZBEKISTAN RAILWAYS"

\begin{tabular}{|l|l|l|l|l|l|}
\hline \multirow{2}{*}{ Years } & \multicolumn{5}{|c|}{ Reproduction rates, \% } \\
\cline { 2 - 6 } & $\mathrm{K}_{\mathrm{vv}}$ & $\mathrm{K}_{\mathrm{vyb}}$ & $\mathrm{K}_{\text {int }}$ & $\mathrm{K}_{\mathrm{pr}}$ & Kiz \\
\hline 2009 & 10,07 & 2,90 & 0,288 & 0,712 & 42,7 \\
\hline 2010 & 9,01 & 3,18 & 0,353 & 0,647 & 41,0 \\
\hline 2011 & 27,7 & 2,74 & 0,099 & 0,901 & 39,2 \\
\hline 2012 & 32,43 & 1,98 & 0,061 & 0,939 & 34,0 \\
\hline 2013 & 9,51 & 3,76 & 0,395 & 0,605 & 38,07 \\
\hline 2014 & 30,42 & 3,51 & 0,115 & 0,885 & 35,25 \\
\hline 2015 & 14,47 & 2,93 & 0,202 & 0,798 & 36,9 \\
\hline 2016 & 13,59 & 2,85 & 0,210 & 0,790 & 38,7 \\
\hline 2017 & 23,27 & 3,22 & 0,138 & 0,862 & 40,2 \\
\hline 2018 & 9,20 & 3,14 & 0,341 & 0,659 & 40,3 \\
\hline
\end{tabular}

The rate of renewal of fixed capital (that is, the share of fixed assets put in place for the year at the end of the year), determined in comparable prices, was in $2009-10.07 \%$, in $2018-9.20 \%$. In general, we can state the fact that the renewal in society is carried out at a tremendous pace. Disposals are carried out at a uniform pace, so if in 2009 the retirement rate was $2.90 \%$, then in 2018 this Figure was $3.14 \%$. A lagging decline in the rate of renewal of fixed capital over the rate of their disposal leads to further accumulation of worn-out physical equipment. 
Statistical data and studies indicate an increase in the recent years of a slight aging of the fixed capital of joint-stock company "Uzbekistan railways".

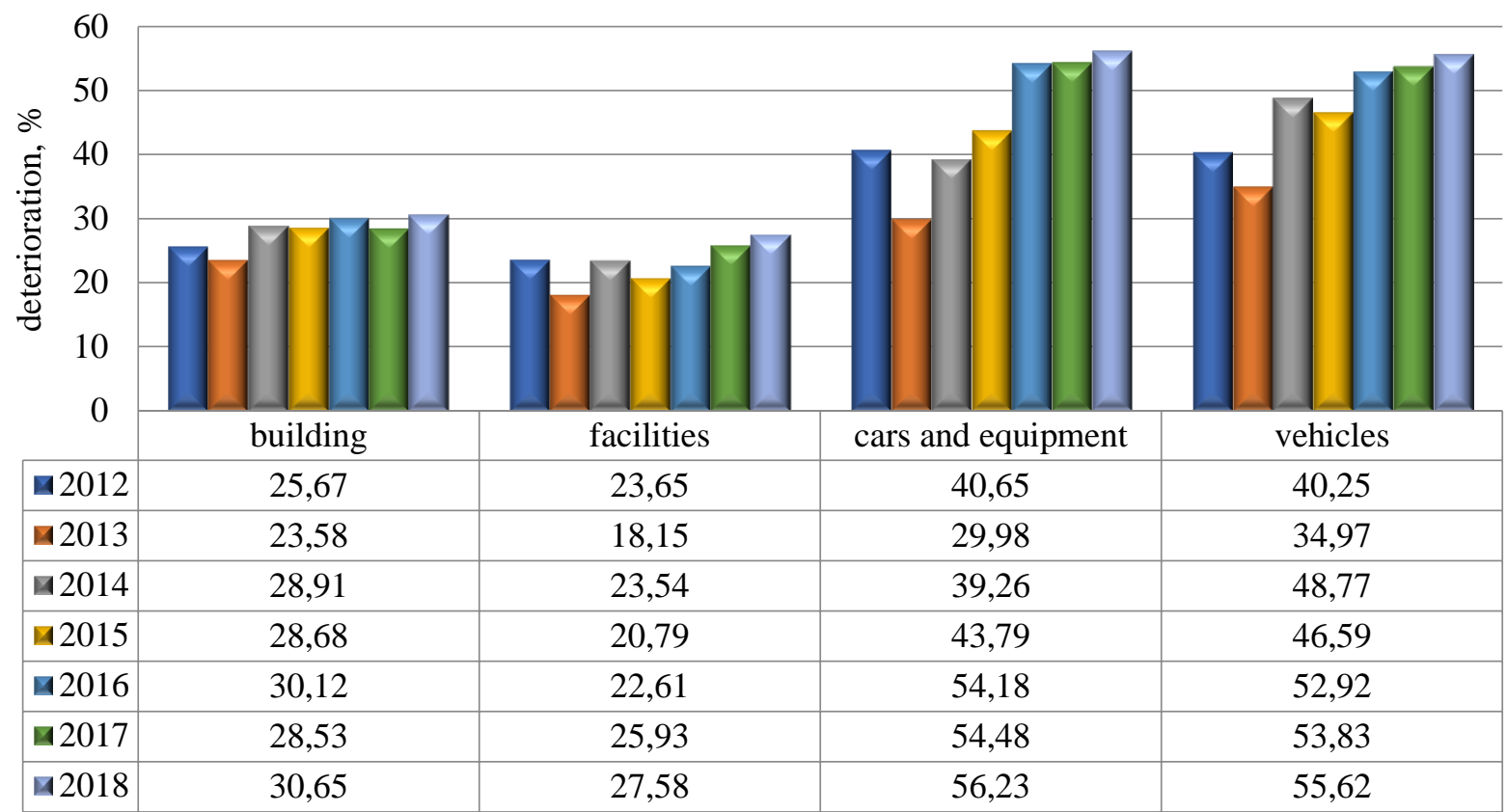

Figure 3. Dynamics of depreciation of fixed capital of JSC "Uzbekistan Railways"

Analyzing the data presented in Figure 3, it should be noted that along with the general decrease in depreciation of fixed assets as a whole, an increase in depreciation is observed for certain groups of fixed assets. In particular, the largest increase in the depreciation rate can be traced in the following groups:

1) buildings and structures — from 2012 to 2018 this ratio increased $3.29 \%$ and $7.75 \%$, respectively;

2) vehicles - for the period 2012-2018. This ratio increased by $1.9 \%$ and amounted to 01.01.2018. 56.8\%.

Indicators of the dynamics of fixed assets were calculated on the basis of the statistical reporting of the company (Form No. 3 - "Report on the movement of fixed assets") for the analyzed period.

Based on the data presented in Fig. 3 we can draw the following conclusions:

1) The input coefficient for 2012-2018. tends to decrease in most groups. Unstable growth is observed in the "Buildings" group (an increase of $2.94 \%$ over the analyzed period) and in the "transfer devices" group. The input factor in such groups of fixed assets as "Facilities", "Machinery and Equipment", "Vehicles" has slightly decreased, although in general the update is carried out at a high rate. So for example, the annual input ratio of "vehicles" does not decrease less than 9-10\%. This is explained by the fact that today the highest depreciation of fixed assets was formed in the active part of fixed assets.

2) The retirement rate, which characterizes the share of fixed assets retired for various reasons (due to decay, wear and obsolescence) in the total value of the value at the beginning of the period, for the analyzed period increased in groups: "Vehicles" (from 2.34\% in 2012, up to 5.10\% in 2018), "Machinery and equipment" (14.61\% in 2012. up to $15.11 \%$ in 2018) and other fixed assets. The data presented show that at the railway company as a whole, worn, unused facilities are being 
decommissioned at an accelerated rate, which, in turn, will further allow the enterprise to more objectively address the problem of reproduction.

3) The growth rate, which characterizes the growth of fixed assets for the period under review, decreased in the "Vehicles" and "Structures" groups, and increased in such groups of fixed assets as "Buildings", "Transfer devices" of fixed assets. For the group of fixed assets "Other", this indicator has a negative value. This indicates an increase in the disposal of fixed assets over their income.

It should also be noted that over the period under review, this indicator for all groups of fixed assets as a whole decreases in dynamics, which indicates that the enterprise is increasing its production capacity to a greater extent due to the intensive approach, i.e. reproduction of fixed assets is carried out on the intensive type.

\section{Conclusions}

In the conditions of market principles of management, an important problem facing the railway company is to increase the efficiency of its work by improving the use of all types of production resources, and above all the basic means of labor. In this regard, the most important strategic task of the railway company is the need to develop new economic methods for managing fixed assets and economic evaluation of their reproduction.

Reproduction of fixed capital is a rather complex and multifactorial process, therefore, when evaluating the author, we propose to use a systematic approach, which is based on the theoretical proposition that fixed capital is designed to save living labor and efficiently use materialized labor - all production resources. Based on the formulated general approach in the author's opinion, it is proposed to carry out an economic assessment of the reproduction of the fixed capital of the jointstock company "Uzbekistan railway" on the basis of three groups of interrelated indicators characterizing:

the technical and economic condition of the fixed capital;

the efficiency of fixed capital;

the availability of resources for the reproduction of fixed capital.

\section{Sources:}

(1). The decree of the President of the Republic of Uzbekistan about "On the forecast of the main macroeconomic indicators and parameters of the state budget of the republic of uzbekistan for 2019 and budget focuses for 2020-2021" PP-4086 of december 26, 2018.

(2). The Message from the President of the Republic of Uzbekistan Shavkat Mirziyoyev to the Oliy Majlis on December 28, 2018.

(3). Data of the joint stock company "Uzbekistan railways". (20/01/2019). http://railway.uz/en/gazhk/statisticheskie-dannye/.

(4). Official Internet resource Republic of Uzbekistan: Common investment in fixed assets. 2017. Available at: https://stat.uz/uploads/docs/investitsiya-yan-dek-2017uz1.pdf/.

\section{References:}

1. Blaug, M. (1994). Ekonomicheskaya teoriya v retrospektive. Moscow: Delo. 437.

2. Samuelson, P. A., \& Nordkhaus, V. D. (2007). Ekonomika. Vil'nyus.

3. Kolegaev, R. N. (1980). Ekonomicheskaya otsenka kachestva i optimizatsiya sistemy remonta mashin. Moscow: Mashinostroenie.

4. Vovk, A. A. (1995). Izmerenie i analiz effektivnosti ispol'zovaniya osnovnykh sredstv. Moscow: MIIT, 104. 
5. Malyshev, Yu. M., Mansurov, A. F., \& Mansurova, T. A. (1998). Osnovnye fondy (finansovo-ekonomicheskii aspekt). Ufa. 48.

6. Mosin, V. N., \& Molodtsova, R. G. (1989). Ratsional'noe ispol'zovanie osnovnykh proizvodstvennykh fondov i ikh effektivnost' $\mathrm{v}$ usloviyakh intensifikatsii obshchestvennogo proizvodstva. Moscow: MINKh, 42.

7. Vovk, A. A. (1999). Izmerenie pokazatelei rentabel'nosti. Ekonomika zheleznykh dorog, (7). 47-53.

8. Dmitrova, S. S. (1979). Puti sovershenstvovaniya obrabotki informatsii ob upravlenii osnovnymi sredstvami na predpriyatiyakh NRB: avtoref. diss. ... kand. ekon. nauk. Moscow: 24.

9. Bezrukikh, P. S. (2002). Bukhgalterskii uchet. Moscow: Bukhgalterskii uchet, 719.

10. Arzilina, A. N. (1994). Bol'shoi ekonomicheskii slovar'. Moscow: Pravovaya kul'tura. 285.

11. Ryabova, T. F. (1996). Bol'shoi kommercheskii slovar'. Moscow: Voina i mir. 400.

12. Konoplitskii, V., \& Filina, A. (1996). Eto biznes: tolkovyi slovar' ekonomicheskikh terminov. Moscow: MSP Al'terpress, 446.

13. Boiko, I. A. (1962). Vosproizvodstvo osnovnykh sredstv zheleznodorozhnogo transporta: avtoref. diss. ... kand. ekon. nauk L., 24.

14. Tereshinoi, N. P. (2011). Ekonomika zheleznodorozhnogo transporta. Moscow. 676.

15. Starr, S. F., \& Cornell, S. E. (2018). The Long Game on the Silk Road: US and EU Strategy for Central Asia and the Caucasus. Rowman \& Littlefield.

\section{Список литературы:}

1. Блауг М. Экономическая теория в ретроспективе. М.: Дело. 1994. 437 с.

2. Самуэльсон П. А., Нордхаус В. Д. Экономика. Вильнюс, 2007.

3. Колегаев Р. Н. Экономическая оценка качества и оптимизация системы ремонта машин. М.: Машиностроение, 1980.

4. Вовк А. А. Измерение и анализ эффективности использования основных средств. М.: МИИТ, 1995. $104 \mathrm{c.}$

5. Малышев Ю. М., Мансуров А. Ф., Мансурова Т. А. Основные фонды (финансовоэкономический аспект). 1998. Уфа. 48 с.

6. Мосин В. Н., Молодцова Р. Г. Рациональное использование основных производственных фондов и их эффективность в условиях интенсификации общественного производства. М.: МИНХ, 1989. 42 с.

7. Вовк А. А. Измерение показателей рентабельности // Экономика железных дорог. 1999. № 7. С. 47-53.

8. Дмитрова С. С. Пути совершенствования обработки информации об управлении основными средствами на предприятиях НРБ: автореф. дисс. ... канд. экон. наук. М.: 1979. 24 c.

9. Безруких П. С. Бухгалтерский учет. М.: Бухгалтерский учет, 2002. 719 с.

10. Арзилина А. Н. Большой экономический словарь. М.: Правовая культура. 1994. 285 c.

11. Рябова Т. Ф. Большой коммерческий словарь. М.: Война и мир. 1996. 400 с.

12. Коноплицкий В., Филина А. Это бизнес: толковый словарь экономических терминов. К.: МСП Альтерпресс, 1996. 446 с.

13. Бойко И. А. Воспроизводство основных средств железнодорожного транспорта: автореф. дисс. ... канд. экон. наук Л., 1962. 24 с. 
14. Терешиной Н. П. Экономика железнодорожного транспорта. М. 2011. 676 с.

15. Starr S. F., Cornell S. E. The Long Game on the Silk Road: US and EU Strategy for Central Asia and the Caucasus. Rowman \& Littlefield, 2018.

Работа поступила

в редакиию 17.01.2019 2.
Принята к публикациии 21.01.2019 2.

Cite as (APA):

Gulamov, A. (2019). Retrospective analysis of reproduction processes of fixed capital of railway transport. Bulletin of Science and Practice, 5(2), 235-244. https://doi.org/10.33619/24142948/39/31 (in Russian).

Ссылка для цчитирования:

Gulamov A. Retrospective analysis of reproduction processes of fixed capital of railway transport // Бюллетень науки и практики. 2019. Т. 5. №2. С. 235-244. https://doi.org/10.33619/2414-2948/39/31. 